\title{
126 配置設計のための階層型最適化法に関する研究
}

\section{Research on Hierarchical Optimization Method for Layout design}

$\begin{array}{llll}\text { 正 } & \begin{array}{lll}\text { 藤田喜久雄 } & \text { (大阪大) } \\ \text { 宮武宏彰 } & \text { (大阪大) }\end{array} \quad \text { 河本将之 } & \text { (大阪大) }\end{array}$

Kikuo Fujita, Osaka University, 2-1, Yamadaoka, Suita, Osaka 565-0871

Masayuki Kawamoto, Osaka University

Hiroaki Miyatake, Osaka University

\begin{abstract}
Under the trends of multi-disciplinary design optimization, modeling techniques and computational algorithms that are configured by following complicatedness of problems have been promoted and gathered much attentions. However, their applicability has been limited within continuously defined problems, while layout optimization is typically complicated but combinatorial. Under this contrast, this paper proposes a hierarchical optimization method for layout design. In the method, a rectangular packing layout problem is hierarchically decomposed into the top-level layout and a series of sub-level layout, those partial layout problems are represented with sequence pair and optimized by genetic algorithms, and they are coordinated through mutual exchange of sets of Pareto optimal solutions explored in the lower levels and ranges of desirable aspect ratio. The validity and effectiveness of the method is investigated through its application to an example problem.
\end{abstract}

Key Words : Layout Design, Hierarchical Optimization, Sequence Pair, Genetic Algorithm, Pareto Optimality

\section{1 緒言}

設計最適化は複雑な設計問題を数学的にモデル化した 上でその範囲内での合理的な解を計算により探索する枠 組みである。この方面では，1990年前後以降の複合領域 設計最適化 (Multi-Disciplinary Design Optimization, MDO) の考え方のもと, 設計問題そのものに潜んでいる複雑さ をモデル化や計算のアルゴリズムに対応付けることによっ て, より強力で実践的な設計最適化の方法論が提案される ようになってきている。一方, 配置設計の問題は, 設計最 適化の展開分野の中でも, 配置すべき要素間の位相的な 位置関係を処理する必要があることから，組合せ最適化 となる困難な問題として位置づけられている(1)が, MDO のもとでの設計最適化の様々な考え方はその方面へはほ とんど展開されていないのが実状である。

本報では，以上の視点のもと，配置設計問題に対して

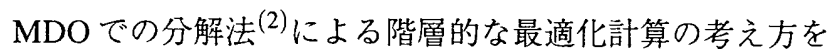

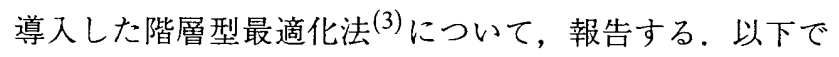
は，まず，配置設計に対して階層型最適化法を構成するた めの考え方とモデル化を示した後に, 各階層の配置問題 を遺伝的アルゴリズムで処理しながら相互の情報交換を 通じて全体としての最適配置を探究する最適化計算の枠 組みを提案し,さらに, 薄型ノートパソコンの具体例から 配置要素とその階層性を定義したある例題に対する適用 例を紹介して，配置設計における階層型最適化法の有効 性について検討を行う。

\section{2 配置問題の階層的なモデル化と設計最適化}

2.1 配置設計問題の動向 配置設計は電子情報機器 から大型プラントまでの多岐に渡る方面の設計課題の中

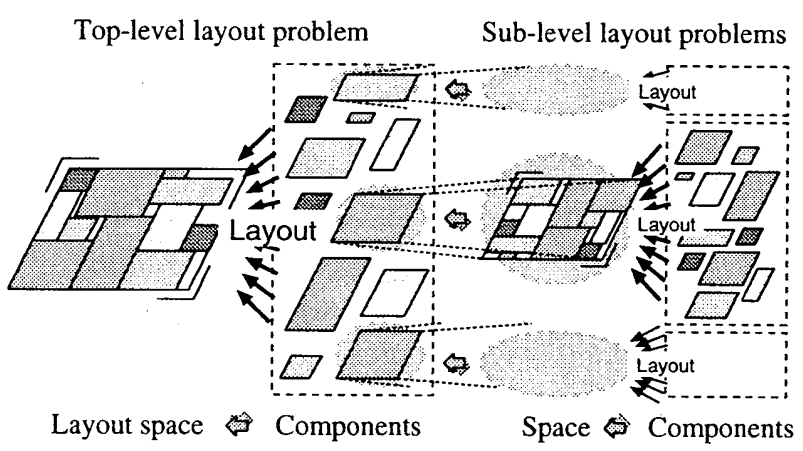

Fig. 1 階層型矩形領域配置設計問題

に見出すことができるが，その基本的な内容は，配置す べき要素の所定の空間内における位置や向きをそれらの 空間的な関係を規定する制約を満たしつつ容積の最小化 などの指標を優れたものとするように決定することにあ $る^{(1)}$.これに対して, 近年, 電子情報機器を典型とする高 密度実装機器などにおいては, 高性能化とともに小型化が 重要事項になっており, 製品全体のパッケージの小型化と ともに，それに適合するようにその構成要素の形状を決 定することが求められるようになってきている，そのよう な状況は，基本的な配置設計における構成内容に対して， 全体パーケージからみればある種のモジュール群となる 各構成要素内の配置問題とそもそもの全体パッケージに おける配置設計問題とを相互に関係付けながら取り扱う 必要性を示唆するものであり, その必要性は, 緒言でも述 べたように，MDOに㧍ける分解法の考え方の配置設計へ の展開を示唆するものであると言える。 


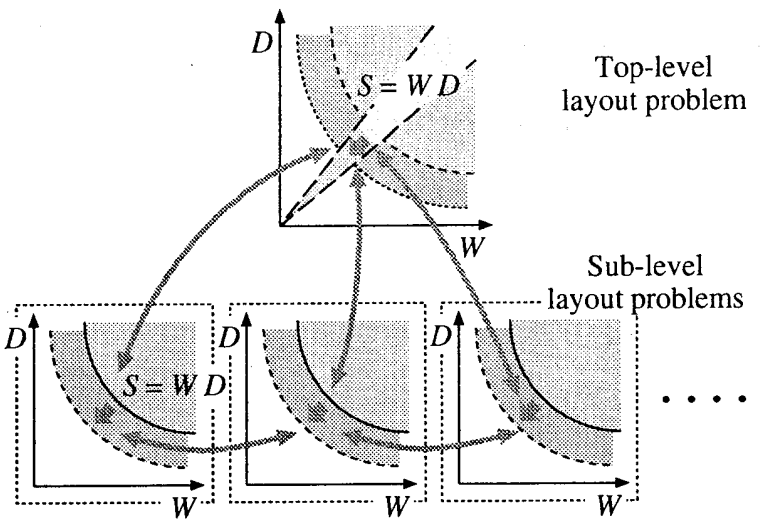

$\leftrightarrow$ Coordination through $\left(\frac{D}{W}\right)_{\min } \leq\left(\frac{D}{W}\right)_{s u b} \leq\left(\frac{D}{W}\right)_{\max }$

Fig. 2 上位レベルでの配置と下位レベルでの配置との 関係

2.2 配置設計問題の階層的なモデル化 前項の動向 を前提として, 配置設計問題における階層型最適化法の 可能性を探究するために，本研究では，Fig. 1に示すよう な以下の条件により規定される階層型矩形領域配置設計 問題を対象とする。

(1) 2 次元平面内の配置問題を考える.

(2) 配置要素はすべて矩形である.

(3) 配置要素 $i$ の形状は，縱横の寸法 $\left(D_{i}\right.$ および $\left.W_{i}\right)$ によ り規定されるか, 縦横比 $r_{i}=\frac{D_{i}}{W_{i}}$ のある範囲内で面積 $S_{i}=W_{i} D_{i}$ を確保することにより規定される.

(4) 配置要素の方位 $\Theta_{i}$ は縦か横のみが許容される.

(5) 配置要素は相互に重なり合わない.

(6) 配置空間全体の領域の形状は矩形とする。

（7）階層性は 2 段階とする.

（8）下位レベルにおける配置空間全体の領域(上位レベル では配置要素の外形に相当する)の形状は矩形とする.

\section{3 配置における最適性と階層性配置設計におけ} る評価指標については，個別的には様々な因子が作用する ものの，原則としては，配置空間全体の最小化が一義的 な内容となる．前項のように, 2 次元配置問題を取り扱う 場合には，縱横比 $r$ を指定された值に近づけつつ, 面積 $S$ を最小化することがその種の指標となる．それに対して， 配置設計問題を上位レベルの全体配置の問題と下位レベ ルの要素内の部分配置の問題に階層的に考える場合, 前 者についての指標はそのようなものとなるが, 後者につ いての指標に関しては, 面積 $S$ の最小化は当然のことで はあるものの, 縦横比 $r$ につてい, 特定の值が指定され るわけではなく，上位レベルでの最適性に貢献し得るもの が望ましいということになる。つまり，上位レベルと下位 レベルの相互の関係のもとで最適化の結果として下位レ ベルの望ましい維横比が定まるということになる。

本研究では, 上記のような最適化過程における上位レべ ルと下位レベルの関係について，Fig. 2 にも示すように，
下位レベルでの各配置を幅 $W$ と奥行 $D$ のそれぞれを最小 化すべき目的関数とした多目的最適化問題として取り扱 うことによって，両者のトレードオフ関係のもとで生成さ れる Pareto 最適解集合を上位レベルの配置に貢献し得る 配置の候補として考える一方で，上位レベルでは，そのよ うな Pareto 最適解集合の分布として許容し得る範囲を下 位レベルの配置を含む配置要素相互の関係を調整しなが ら段階的に絞り込むことによって，全体としての配置を調 整していくことを着想として，階層的な配置設計最適化 法を構成する。

\section{3 配置設計のための階層型最適化法}

3.1 基本構成前節で導いた着想のもとで構成され る階層型最適化法の骨子は以下の通りである.

・各レベルでのそれぞれの配置は, 要素間の位相的な位 置関倸を Sequence Pair ${ }^{(4)}$ により表現し，パッキング 問題を解くことにより各要素の位置と寸法を定める.

- Sequence Pairによって表現された位相的な位置関係 は遺伝的アルゴリズムにより最適化する。

-上位レベルと下位レベルの遺伝的アルゴリズムによ る最適化は並行的に進めて，一定の世代毎に相互の もたらす暫定的な結果を交換することによって，両 者の調整を行っていく.

以下では，これらの具体的な内容の要点について述べる.

3.2 Sequence-pairによる位置表現 Fig. 3 は, 図中 (a)に示す a, b, c, dの 4つの要素の場合を引いて, Sequence Pairによる配置表現とそのもとでの位置寸法の決定手続き を例示したものである.

まず, Sequence Pair では，図中 (b)のような $\left(\Gamma_{+}, \Gamma_{-}\right)$な

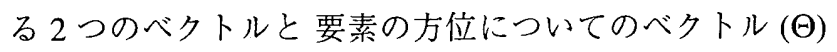
により要素間の位相的な関係を表現する，そのもとで， $\Gamma_{+}$ と「ーに従い，各要素を図中 (c) に示すようにして斜交グ ラフに割り付け，そのグラフ上での位置関係に従って，図 中 (d) と (e) に示すような水平方向の制約グラフ $G h$ と垂 直方向の制約グラフ $G v$ を導き出す。このとき, 例えば, 要素 $\mathrm{x}$ とyの間に

$$
\Gamma_{-}^{-1}(\mathbf{x})<\Gamma_{-}^{-1}(\mathrm{y}), \quad \Gamma_{+}{ }^{-1}(\mathrm{x})<\Gamma_{+}{ }^{-1}(\mathrm{y})
$$

という関係が成立していれば， $\mathrm{x}$ は $\mathrm{y}$ の左に位置すること を意味する制約が導出され，また，

$$
\Gamma_{-}^{-1}(\mathbf{x})<\Gamma_{-}^{-1}(\mathbf{y}), \quad \Gamma_{+}^{-1}(\mathbf{x})>\Gamma_{+}^{-1}(\mathbf{y})
$$

という関係が成立していれば， $\mathrm{x}$ は $\mathrm{y}$ のに位置すること

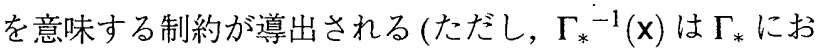

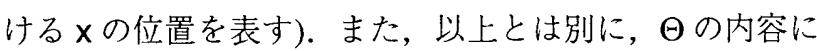
応じて, 各要素の方位が定められ, 制約グラフの $G h$ と $G v$ に当該の要素の長さが図中 (d) と (e)のように与えられる ことになる。 


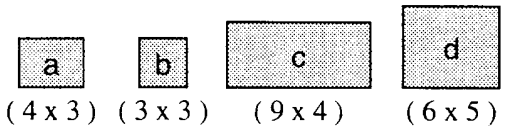

(a) 配置要素 $a, b, c, d$ の形状

$\operatorname{Seq}-\operatorname{Pair}\left(\Gamma_{-}, \Gamma_{+}\right)=(\mathrm{a}, \mathrm{d}, \mathrm{b}, \mathrm{c} ; \mathrm{b}, \mathrm{c}, \mathrm{a}, \mathrm{d})$

(b) それらについての Sequence Pair 表現例

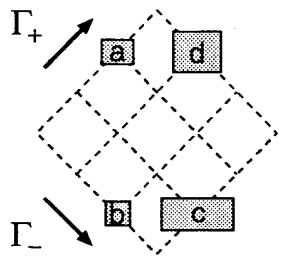

(c) Sequence Pair の斜交 グラフへの割り付け

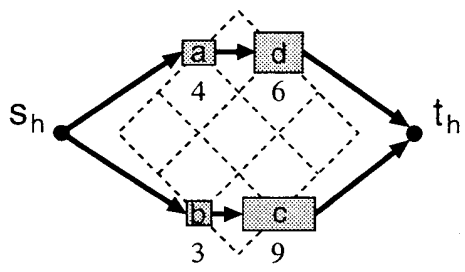

(d) $G h ;$ 水平方向 の制約グラフ

(e) $G v$; 垂直方向 の制約グラフ

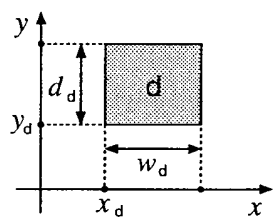

(f) 位置変数

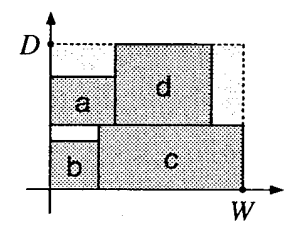

(g) パッキング結果

Fig. 3 Sequence Pair による配置表現とパッキング処理

続いて，各要素に対して制約グラフの $G h$ と $G v に$ に含ま れている各制約パス (図中の太い矢印の列)に対して, 図 中 (f)のようにそれぞれに位置や寸法についての変数を設 定した上で，それぞれに含まれるすべての要素の幅 $w_{i}$ も しくは奥行 $d_{i}$ の総和を求め, その值が最大となるパス(ク リティカルパス)における総和から，当該の配置問題につ いての配置空間の幅 $W$ と奥行 $D$ を決定し, あわせて, 図 中 $(\mathrm{g})$ のように, 各要素の位置や寸法(パッキング)を最終 的に決定するようにする.

3.3 配置要素の種別とそれぞれの取扱い 配置要素 はすべて矩形であるが， 2.2 項で設定した条件 (3) および 2.3 項で示した着想のもと, その形状には以下に示す $3 つ$ の形式のものが混在している.

Hard : その形状の幅と奥行が不変である要素.

Soft：面積を一定に保ったまま，ある範囲の縦横比を採 ることができる要素.

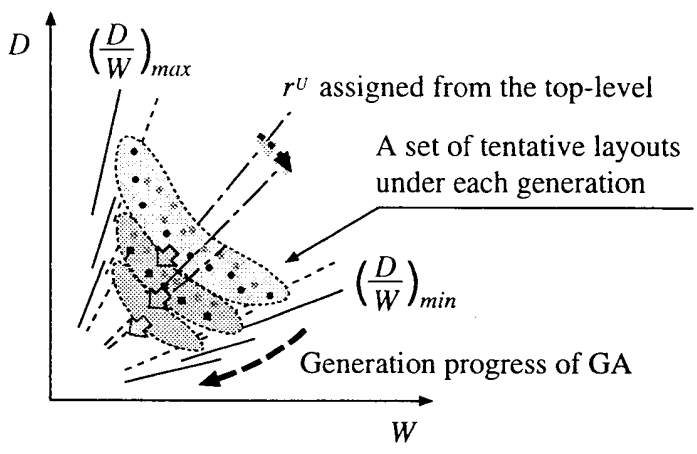

Fig. 4 下位レベルでの探索のメカニズム

Discrete：幅と奥行を有限個の組合せの中から選択する ことによりその形状が定められる要素。

Sequence Pair とそれによる配置の具体化についての前項 での説明はすべての要素が Hardに分類されることを前提

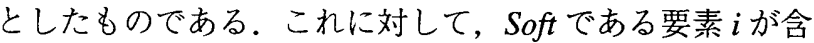
まれる場合には，前項で Fig. 3(f)のようにして導入した 変数群にSoft な要素の粕横比を加えて構成する設計変数 のもとで当該パスの長さを最小化すべき目的関数として 単純 $\mathrm{GA}$ を実行することによって，図中 $(\mathrm{g})$ に相当する配 置を決定する．また，上位レベルの配置において，下位レ ベルのある配置 $j$ で定められている Pareto 最適解集合か ら当該の要素 $j$ の形状を選択的に定める必要がある場合 には，それをDiscreteな要素として位置付けて，Soft 要素 が含まれる場合に準じた取扱いにより，図中 $(\mathrm{g})$ に相当す る配置を決定するようにする。

3.4 各レベルにおける最適化手法 各レベルで用 いる遺伝的アルゴリズムについては，上位レベルでは， Sequence Pairのもとでの配置設計に実績のある Adaptive Genetic Algorithm (EAGA) ${ }^{(5)}$ を用いる. その際の目的関数 には，2.3 項での議論を踏まえつつ，幅と奥行についての 目標値をそれぞれ $W_{0}$ と $D_{0}$ として与えた上で，次式によ る幅 $W$ と奥行 $D$ を変数とした目的関数を導入する。

$$
F(W, D)=C_{1} \frac{W D}{W_{0} D_{0}}+C_{2}\left|\frac{W}{D}-\frac{W_{0}}{D_{0}}\right|
$$

ここで，上記の第 1 項は面積についての目標值に対する 比率を, 第 2 項は維横比についての目標值からのずれに 対応するものであり， $C_{1}$ と $C_{2}$ は両者に対する重み付けの 定数である. 本研究では, 両者のバランスのもとで, 縦横 比をある程度の範囲に抑えながら面積の最小化を行って いくことを意図している。

一方，下位レベルについては，対象問題が多目的最適化問 題となることを受けて，Neighborhood Cultivation Genetic Algorithm (NCGA) $)^{(6)}$ のメカニズムを組み込んだ最適化を 行うことによって，上位レベルでは Discrete の内容となる Pareto 最適解集合を, 適宜, 求めていく. 本研究では, そ の際，Fig. 4 にも示すように，許容できる縦横比の範囲を 遺伝的アルゴリズムの進渉とともに徐々に絞り込んでい 
Table 1 例題における配置要素の構成

\begin{tabular}{|c|c|c|c|c|c|}
\hline No & kind & $W$ & $D$ & $S$ & $r$ \\
\hline \hline 1 & Hard & 104 & 70 & & \\
\hline 2 & Soft & & & 306 & $0.5 \sim 2.0$ \\
\hline 3 & Soft & & & 144 & $4.0 \sim 2.5$ \\
\hline 4 & Soft & & & 1575 & $2.0 \sim 0.5$ \\
\hline 5 & Hard & 17 & 25 & & \\
\hline 6 & Hard & 35 & 18 & & \\
\hline 7 & Hard & 12 & 30 & & \\
\hline 8 & Soft & & & 1680 & $1.5 \sim 0.5$ \\
\hline 9 & Hard & 106 & 72 & & \\
\hline 10 & Soft & & & 200 & $4.0 \sim 2.5$ \\
\hline 11 & Hard & 8 & 45 & & \\
\hline 12 & Soft & & & 2800 & $2.0 \sim 0.5$ \\
\hline 13 & Hard & 70 & 40 & & \\
\hline 14 & Hard & 35 & 35 & & \\
\hline 15 & Soft & & & 300 & $2.0 \sim 0.5$ \\
\hline 16 & Soft & & & 250 & $3.0 \sim 0.5$ \\
\hline 17 & Soft & & & 140 & $2.0 \sim 0.5$ \\
\hline 18 & Hard & 29 & 15 & & \\
\hline 19 & Soft & & & 460 & $2.0 \sim 0.5$ \\
\hline 20 & Soft & & & 1200 & $1.0 \sim 0.2$ \\
\hline 21 & Hard & 35 & 35 & & \\
\hline 22 & Discrete ( sub-level 1 に対応する) \\
\hline 23 & Discrete ( sub-level 2 に対応する) \\
\hline 24 & Discrete ( sub-level 3 に対心する \\
\hline
\end{tabular}

\begin{tabular}{|c|c|c|c|c|c|}
\hline No & kind & $W$ & $D$ & $S$ & $r$ \\
\hline \hline 1 & Hard & 10 & 13 & & \\
\hline 2 & Hard & 22 & 18 & & \\
\hline 3 & Hard & 22 & 18 & & \\
\hline 4 & Hard & 42 & 10 & & \\
\hline 5 & Soft & & & 975 & $2.0 \sim 0.5$ \\
\hline 6 & Soft & & & 170 & $1.5 \sim 0.5$ \\
\hline 7 & Soft & & & 255 & $1.5 \sim 0.5$ \\
\hline 8 & Soft & & & 170 & $1.5 \sim 0.5$ \\
\hline 9 & Soft & & & 1800 & $1.5 \sim 0.5$ \\
\hline
\end{tabular}

sub-level2

\begin{tabular}{|c|c|c|c|c|c|}
\hline No & kind & $W$ & $D$ & $S$ & $r$ \\
\hline \hline 1 & Hard & 86 & 42 & & \\
\hline 2 & Hard & 50 & 50 & & \\
\hline 3 & Soft & & & 520 & $2.0 \sim 0.5$ \\
\hline 4 & Hard & 30 & 26 & & \\
\hline 5 & Soft & & & 2736 & $3.0 \sim 1.0$ \\
\hline
\end{tabular}

sub-level3

\begin{tabular}{|c|c|c|c|c|c|}
\hline No & kind & $W$ & $D$ & $S$ & $r$ \\
\hline \hline 1 & Hard & 14 & 35 & & \\
\hline 2 & Hard & 14 & 46 & & \\
\hline 3 & Soft & & & 1749 & $2.0 \sim 0.5$ \\
\hline 4 & Hard & 28 & 28 & & \\
\hline 5 & Soft & & & 320 & $1.0 \sim 0.2$ \\
\hline 6 & Hard & 30 & 30 & & \\
\hline 7 & Soft & & & 416 & $1.0 \sim 0.2$ \\
\hline 8 & Soft & & & 230 & $1.0 \sim 0.2$ \\
\hline 9 & Soft & & & 989 & $2.0 \sim 0.5$ \\
\hline 10 & Hard & 60 & 14 & & \\
\hline 11 & Hard & 60 & 14 & & \\
\hline
\end{tabular}

くことを通じて，段階的に Pareto 最適解集合の精度を上 げていくようにすることを意図している.

3.5 階層間での協調処理階層型最適化法における 鍵は各部分問題の間での協調処理をどのように調整する かにある. 本研究では, Fig. 2でも示したように, 上位レ ベルでの全体最適化と下位レベルでの部分最適化を並行 的に進めていき，それらの間で必要な情報を交換すると ともに，その交換のタイミングを，適宜，調整することに よって，優れた配置解を導出することを狙っている．それ に向けては，以下の方針を採ることにする。

・上位レベルから下位レベルに対しては, 下位レベル の各部分問題に相当するDiscrete 要素のその時点に おける縦横比の典型的な值を伝達する。下位レベル では，そのような典型的な值の付近に分布する Pareto 最適解集合を重点的に探索するようにする。

-下位レベルから上位レベルに対しては，その時点に おける Pareto 最適解集合の縦横比を上位レベルに伝 達する，上位レベルでは，それらをもとにDiscrete 要 素の具体的な内容を定めて，その範囲内での全体配 置を探索するようにする.

・上位レベルと下位レベルとの間の情報交換はそれぞ れの遺妘的アルゴリズムにおける世代交代がそれぞれ に一定数繰り返されたタイミングで行うものとする。 なお，情報交換のタイミングについては，探索の精度や効 率に影響を及ほすことから，具体的な計算例における様 子を踏まえて，個々に設定することが求められる。

\section{4 数值実験}

4.1 例題の構成前節の階層型最適化法をある薄型 ノートパソコンとその構成要素の形状を参照して構成した 例題に適用することによって，その妥当性や有効性を検証 する. Tabel 1 はその例題における各レベルの配置問題の 内容を示したものである，上位レベルの問題は，10 個の Hard 要素, 11 個の Soft 要素, 3 個の Discrete 要素, 合計 24 個の要素から構成されており，それらのうち，Discrete 要素に対応する下位レベルの問題は，それぞれ，9個，5個， 11 個の要素から構成されている。 また, 以上のような構成 に対して，配置の目標を式 (1)で定義した目的関数に対し て $W_{0}=300, D_{0}=190$ (このとき, $S=57000, r=0.633$ ) として与えるものとする.

4.2 最適化法の構成上記の例題に対する最適化法 を以下のように構成する。

- 式 (1) による目的関数の内容を経験的に $C_{1}=1$ およ び $C_{2}=2$ により定める.

- 各部分問題での個体数はいずれも 100 個とする.

-上位レベルと下位レベルとの間の情報交換は以下の タイミングで行う.

๖上位レベルについては，100世代までは 10 世代 毎に，それを超えて 1,000 世代までは 50 世代毎 に，それを超えて 2,000 世代までは 100 世代每 に，それ以降は 1,000 世代毎に下位レベルとの 情報交換を行う。

๖下位レベルについては，常に200世代毎に上位 


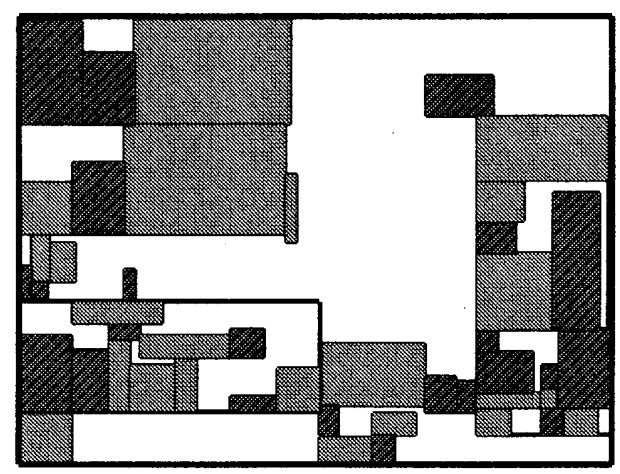

(a) Layout at 1st generation ( $S=114448, \frac{D}{W}=0.741$ )

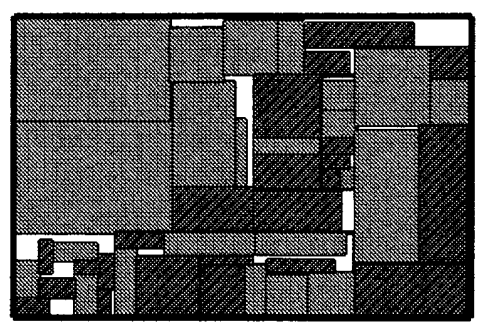

(d) Layout at 2,000th generation ( $S=59921, \frac{D}{W}=0.653$ )

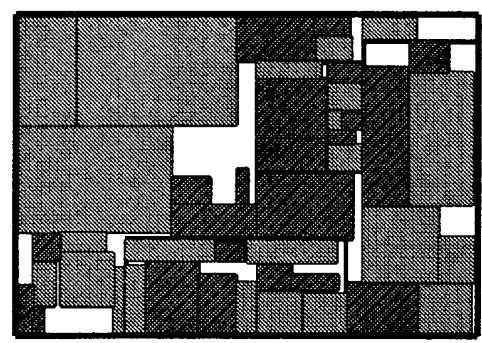

(b) Layout at 300 th generation ( $S=64165, \frac{D}{W}=0.686$ )

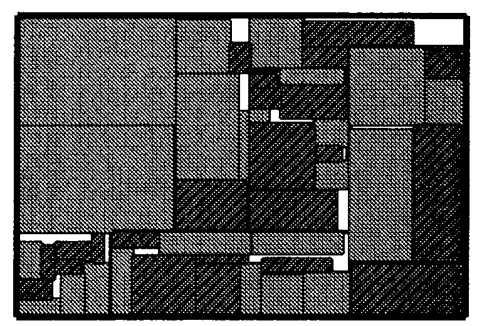

(e) Layout at 3,500th generation ( $S=59012, \frac{D}{W}=0.663$ )

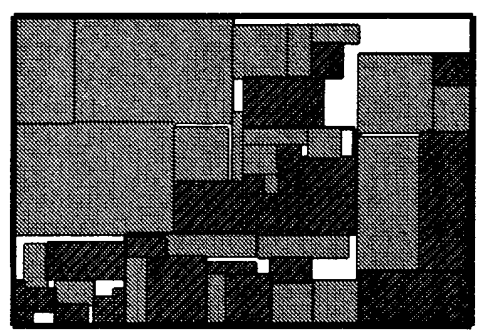

(c) Layout at 1,000th generation ( $S=61335, \frac{D}{W}=0.665$ )

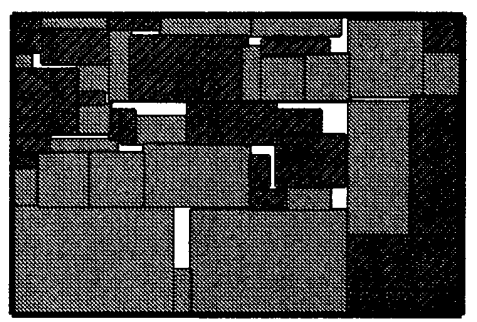

(f) Layout at 5,000th generation ( $S=58698, \frac{D}{W}=0.660$ )

Fig. 5 代表世代における配置図

レベルとの情報交換を行う.

これにより，初期段階では下位レベルを重点的に，終 盤では上位レベルを重点的に探索することを意図する。

・上位レベルの世代数が 5,000 に達した時点で探索を 終了する。

4.3 結果と考察 Fig. 5 は前出の例題に対して上記 の最適化法を適用した際の代表世代における暫定的な最適 配置の履歴を示したものである. 網かけしていないブロッ クがHard 要素であり, 網掛けしているブロックがSoft 要 素, 太枠で囲んでいるブロックが Discrete 要素つまり下位 レベル配置の外形となる，世代が進むにつれて，縦横比は 目標値に近づきながらも全体の面積は小さくなり，下位レ ベルの各部分配置も徐々に小さくなっていく様子を確認で きる。

Figs. 6，7，8 は式 (1) で定義される目的関数, 面積及び 緥横比の值を最良個体の持つ值と最悪個体が持つ值, およ び個体間の平均を 10 世代ごとにプロットしたものである. 最良個体に関して, 目的関数值は, 初期段階で大きく減少 した後，世代が進むにつれて少しずつ階段状に減少して いっている，また，面積や縦横比も目標値に振動しながら 徐々に目標値に近づいていっていることが確認できる。一， 方, 最悪個体および平均値の遷移からは, 探索の過程を通 じて個体群の多椂性が保持されていることを確認できる.

さらに，Fig. 9 は下位レベルの部分配置 sub-level3にお ける世代毎の暫定 Pareto 最適解集合の推移を示している。 世代が進むに連れて Pareto 最適解集合が前進している様

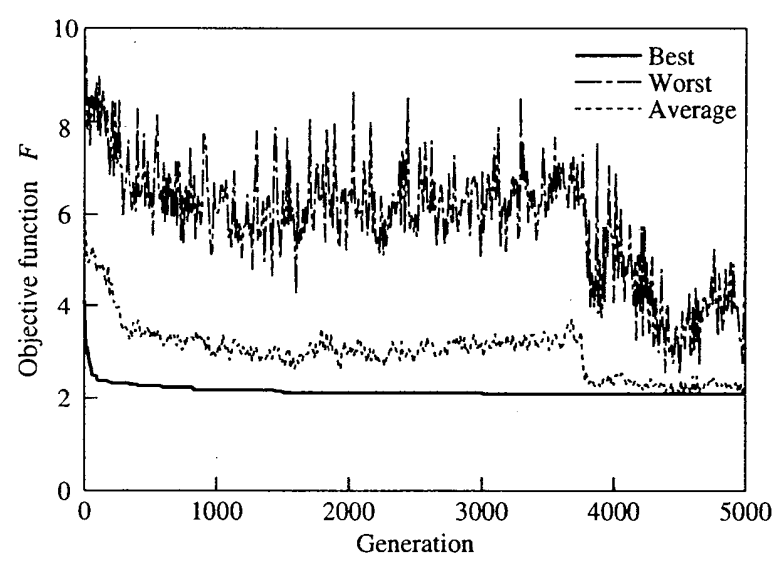

Fig. 6 上位レベルにおける目的関数 $F$ の履歴

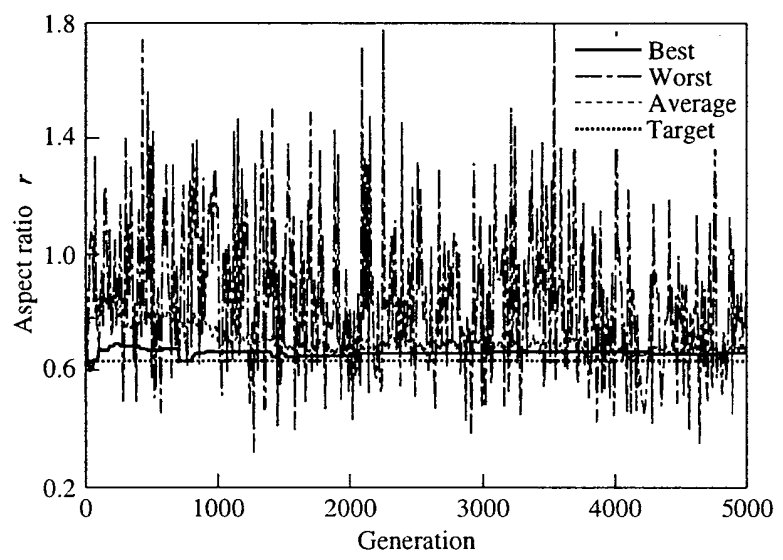

Fig. 7 上位レベルにおける縦横比 $r$ の履歴 


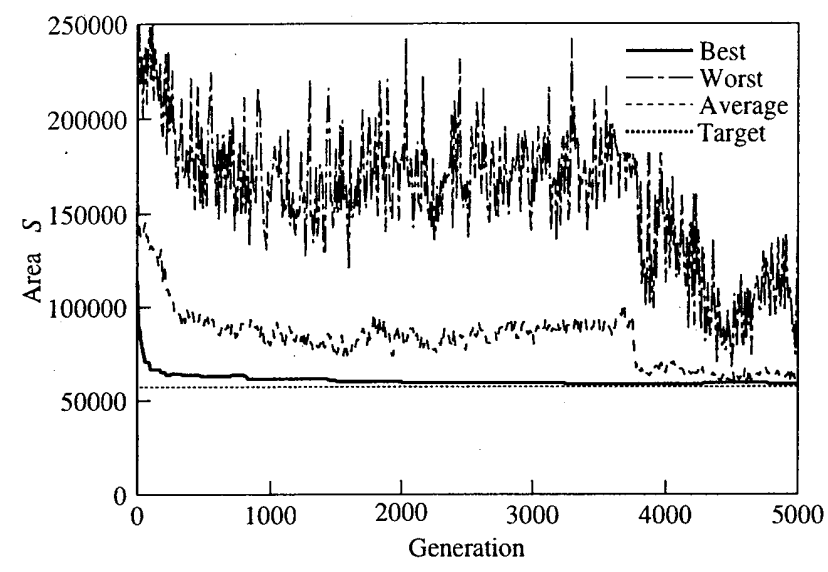

Fig. 8 上位レベルにおける面積 $S$ の履歴

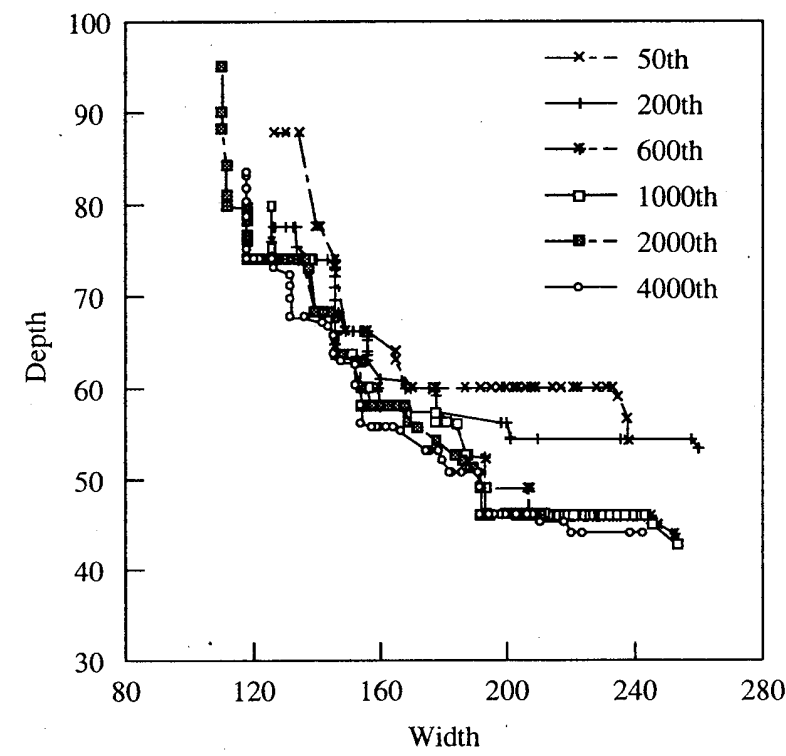

Fig. 9 下位レベル sub-level3 における暫定 Pareto 最適 解集合の推移

子がわかる，また，それらが分布する範囲が上位レベルか ら伝えられる縦横比の推奨值に従って遷移していく様子 も確認することができる。

\section{5 結言}

本報では，様々な最適設計問題の中でも組合せ最適化問 題となり困難であるとされる配置設計問題に対して, 複合 領域最適最適化 (MDO) の動向のもとで試みが進んでいる 対象問題の構造に基づいてモデル化とアルゴリズムを構 成することによってより合理的な設計最適化を行拀うと する階層型最適化法の考え方を展開し，あわせて，構成し た最適化法を階層型矩形領域配置設計の例題に適用して, その有効性を検証した，本報での検証内容では，配置要素 間の位置関係についての制約条件が考慮されていないな どの面で，実用的には不足するところもあるものの，基本 的な考え方として，配置設計に対して階層的な最適化法を 導入する意義とその潜在的な可能性を示すことができた
と考えている．今後は，そのような制約条件が取り扱える ようにするなどして，配置設計のための階層型最適化法を より実践的なものへと進化させていきたいと考えている。

\section{文 献}

(1) 藤田, 最適設計ハンドブック, 第 III 部-5.1 節, 機械系におけ る配置設計, (2003), pp. 355-362, 朝倉書店.

(2) Kim, H. M., Michelena, N. F., Papalambros, P. Y., and Jiang, T., "Target Cascading in Optimal System Design," Transactions of the ASME, Journal of Mechanical Design, Vol. 125, No. 3, (2003), pp. 474-480.

(3) Fujita, K., Kuriyama, M. and Suyama, T., "A Perspective of Hierarchical Layout Design Optimization for Highly Packed Equipment," Proceedings of the 2007 ASME Design Engineering Technical Conferences and Computers and Information in Engineering Conference, (2007), Paper No. DETC2007-35189.

(4) Murata, H., Fujiyoshi, K. and Kajitani, Y., "VLSI Module Placement based on Rectangle-Packing by the Sequence-Pair," IEEE Trans. on Computer-Aided Design of Integrated Circuits and Systems, Vol. 15, No. 12, (1996), pp. 1518-1524.

(5) Nakata, S., Koide, T. and Watanabe, S., "An Adaptive Genetic Algorithm for VLSI Floorplanning based on Sequence-Pair," Proceedings of IEEE International Symposium on Circuits and Systems, Vol. 3, (2000), pp. 65-68.

(6) Watanabe, S., Hiroyasu, T. and Miki, M., "Neighborhood Cultivation Genetic Algorithm for Multi-Objective Optimization Problems," Proceedings of the 4th Asia-Pacific Conference on Simulated Evolution And Learning (SEAL-2002), (2002) , pp. 198202. 